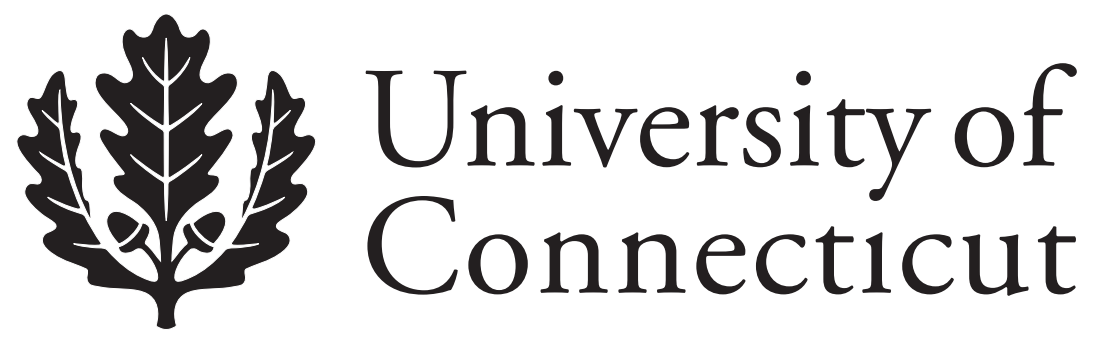

Department of Economics Working Paper Series

Total Factor Productivity and Monetary Policy: Evidence from Conditional Volatility

Nicholas Apergis

University of Macedonia

Stephen M. Miller

University of Connecticut and University of Nevada, Las Vegas

Working Paper 2007-06

March 2007

341 Mansfield Road, Unit 1063

Storrs, CT 06269-1063

Phone: (860) 486-3022

Fax: (860) 486-4463

http://www.econ.uconn.edu/

This working paper is indexed on RePEc, http://repec.org/ 


\begin{abstract}
This paper empirically assesses whether monetary policy affects real economic activity through its affect on the aggregate supply side of the macroeconomy. Analysts typically argue that monetary policy either does not affect the real economy, the classical dichotomy, or only affects the real economy in the short run through aggregate demand new classical theories. Real business cycle theorists try to explain the business cycle with supply-side productivity shocks. We provide some preliminary evidence about how monetary policy affects the aggregate supply side of the macroeconomy through its affect on total factor productivity, an important measure of supply-side performance. The results show that monetary policy exerts a positive and statistically significant effect on the supply-side of the macroeconomy. Moreover, the findings buttress the importance of countercyclical monetary policy as well as support the adoption of an optimal money supply rule. Our results also prove consistent with the effective role of monetary policy in the Great Moderation as well as the more recent rise in productivity growth.
\end{abstract}

Journal of Economic Literature Classification: E32; E51

Keywords: Total Factor Productivity; Monetary Policy; Volatility; GARCH models

The authors express their gratitude to Parantap Basu, three anonymous referees of this journal and the Editor of International Finance for their valuable comments and suggestions on an earlier draft of this paper. Needless to say, the usual disclaimer applies. 


\title{
Total Factor Productivity and Monetary Policy: Evidence from Conditional Volatility
}

\begin{abstract}
This paper empirically assesses whether monetary policy affects real economic activity through its affect on the aggregate supply side of the macroeconomy. Analysts typically argue that monetary policy either does not affect the real economy, the classical dichotomy, or only affects the real economy in the short run through aggregate demand - new Keynesian or new classical theories. Real business cycle theorists try to explain the business cycle with supply-side productivity shocks. We provide some preliminary evidence about how monetary policy affects the aggregate supply side of the macroeconomy through its affect on total factor productivity, an important measure of supply-side performance. The results show that monetary policy exerts a positive and statistically significant effect on the supply-side of the macroeconomy. Moreover, the findings buttress the importance of countercyclical monetary policy as well as support the adoption of an optimal money supply rule. Our results also prove consistent with the effective role of monetary policy in the Great Moderation as well as the more recent rise in productivity growth.
\end{abstract}

\section{Introduction}

The classical dichotomy argues that monetary policy (i.e., changes in the interest rate as the benchmark policy instrument) do not exert real effects on the economy. Rather, changes in monetary policy lead to changes in the overall level of prices, but do not induce relative price adjustments. Violations of, or exceptions to, the classical dichotomy permeate the existing literature. New classical and new Keynesian theories of macroeconomic adjustment both restrict the classical dichotomy to long-run equilibrium, arguing the monetary policy exerts real effects in the short run. Deviations of real output from trend or potential, however, occur, for example, because of misperceptions about the actual price level or because of nominal wage and price rigidities. That is, the received wisdom sees monetary policy affecting real economic activity through the aggregate demand side of the economy.

This paper empirically assesses whether monetary policy affects real economic activity through the aggregate supply side of the macroeconomy. More specifically, we consider how monetary policy affects total factor productivity, that part of the total economy's output not 
explainable by the economy's factors of production -- capital, labor, and so on. More specifically, changes in technology and education can make factor inputs more productive and this change in productivity aggregates to total factor productivity. These latter changes appear in the Solow residual or changes in total factor productivity (Solow, 1957). In sum, we investigate a conjecture by Chatterjee (1999) about the possible sources of lower cyclicality in output and, in particular, whether monetary policy volatility, proxied by measures of monetary policy variables, such as the federal funds rate, non-borrowed reserves, and the ratio of non-borrowed reserves to total reserves (Christiano et al., 1999), affects total factor productivity (TFP) volatility in the US.

Kim and Nelson (1999), McConnell and Perez-Quiros (2000), Blanchard and Simon (2001), and Stock and Watson (2002), among others, document the reduction in the volatility of U.S. GDP growth that began in the early 1980s, dubbed the Great Moderation. Moreover, Clarida et al. (2000), Stock and Watson (2002), and Kahn et al. (2002) provide a list of explanations regarding the fall of business cycle volatility that includes among other factors, improvements in management techniques, smaller volatility of structural shocks hitting the economy, and improved monetary policy. We consider a deeper issue of the possible effect of monetary volatility on TFP volatility, providing direct practical implications for domestic monetary policy. TFP volatility also decreased by 50 percent after 1984 (Kim and Nelson, 1999; McConnell and Perez-Quiros, 2000; Stock and Watson, 2002). A countercyclical monetary policy may prove most appropriate to smooth out business cycle fluctuations when monetary policy volatility exerts an effect on TFP volatility. In addition, the discovery of such a relationship suggests that central banks should take seriously the target of output stability and set the appropriate weight on it (Floden, 2000).

Business cycle theory bifurcates crudely into classical and Keynesian branches. The real 
business cycle proponents attempt to explain short-run business cycle movements, as well as the level and path of trend or potential output entirely with real factors, including crucially productivity shocks. Monetary policy plays little or no role in the real business cycle literature. Tobin (1965) develops a monetary growth model, where monetary policy can affect the implicit rate of return on money relative to the real return on capital, leading to portfolio shifts that alter trend or potential output. The empirical evidence, however, generally finds a negative effect, especially at higher rates of inflation (Fisher 1992; Bruno and Easterly 1998; Burdekin et al. 2004). ${ }^{1}$ Other authors (Sinai and Stokes 1972; Short 1979; Hasan and Mahmud 1993) directly test for money as a productive asset in the production function, in addition to capital and labor. Money improves the efficiency of the other physical inputs. Other papers concentrate on several aspects of the role of money in production, such as the differential productivity effect of money (e.g., Chowdhury and Liu, 1995) and the role of anticipated and unanticipated money balances (e.g., Beladi and Samanta, 1988). DeLorme et al. (1995) and Nouzard (2002), for example, focus on the efficiency role of money in production. As such, we argue that, if true, then money affects $\mathrm{TFP}^{2}$

Lucas (1994) argues that monetary policy in the US over the post-war period proved better than over the pre-war period. Post-war monetary policy prevented monetary instabilities from affecting business cycles. Bernanke and Gertler (1989), however, argue that countercyclical monetary policy can play a substantial role in promoting efficient responses to TFP changes,

\footnotetext{
${ }^{1}$ The Tobin (1965) model receives criticism for not incorporating a productive role for money and for implicitly assuming ad hoc behavioral underpinnings in the model. Several strands of related literature consider the existence of money in the utility or production function, the role of transactions costs in generating a positive demand for money, and the role of money in facilitating intertemporal substitution of resources. See Walsh (2003) for more details.

${ }^{2}$ That is, money or monetization of the macroeconomy may enter into the determination of TFP as can technology and human capital.
} 
since down payments and/or equity position requirements make investments responsive not only to TFP changes but also to short-term interest rates. The effects of macroeconomic variables on TFP have received little attention. In general, these effects occur indirectly, since these variables appear in the set of exogenous determinants of economic environment of any productive activity.

Caballero and Lyons (1992), Basu and Kimball (1994), and Basu $(1995,1996)$ note that TFP significantly correlates with aggregate activity. Evans (1992) argues that not only do exogenous technology shocks propel business fluctuations but also monetary policy variables affect TFP. In contrast, Jun (1998) believes that no reason justifies why productivity fluctuations correlate with specific components of the money supply, such as, non-borrowed reserves and/or the monetary base.

The rest of the paper is organized as follows. The next section presents the empirical results to provide additional evidence on the association between TFP volatility and money volatility. The final section concludes.

\section{Empirical Analysis}

A. Data

The empirical analysis uses U.S. quarterly data on real output (Y) proxied by real GDP less farm, housing, and ex oil production, three different measures of monetary policy -- the federal funds rate (FFR), non-borrowed reserves (NBR), and non-borrowed reserves to total reserves (NBRTR), labor (L) measured as the index of working hours $(1995=100)$, the total capital stock (K) measured as the net stock of non-farm, non-residential fixed assets and consumer durables, an adjustment cost variable ( $\mathrm{J}$ ) for capital and labor calculated by a technique developed by Braun and Evans (1998), and the state of technology proxied by the number of patents (PAT). Data cover the period 1975 to 2004 and come (except from the capital stock and the number of 
patents) from the International Financial Statistics CD-Rom. The capital stock and the number of patents data come from Business Statistics. In addition, we also use annual data on all variables plus the Multi Factor Productivity (MFP) measure from the Bureau of Labor Statistics (BLS) over the period 1975 to 2001 . For our empirical purposes, the capacity utilization ratio (UTIL) equals the ratio of actual real income to potential real income. Potential output comes from an "off-the-shelf" measure of OECD output gaps. That is, we use OECD output gaps for the U.S. to generate our potential output series. Moreover, we convert the data to per capita values by dividing them by the civilian population, sixteen years and older (data on population measures were obtained from the UN population statistics). Finally, we employ the RATS 6.1 software for our empirical analyses.

\section{B. Integration Analysis}

We first test for non-stationarity by using unit-root tests proposed by Dickey and Fuller (1981). Table 1 reports the results from ADF unit-root tests. We fail to reject the hypothesis of a unit root at the 1-percent level for real output, capacity utilization, the federal funds rate, nonborrowed reserves, total reserves, capital, labor, TFP, MFP, the number of patents, and the adjustment cost variable. Using first differences, we reject non-stationarity for all variables.

We also employ the KPSS test proposed by Kwiatkowski et al. (1992). We apply this test with a trend in their levels and without a trend in their first differences, conforming to existing practice in the literature. Finally, we report the KPSS results, using 0, 2, 4, and 8 lags. Once again, we do not reject the hypothesis of a unit root for all variables under study at the 1-percent level. Using first differences, we, once again, reject unit root non-stationarity.

Finally, we consider the Perron (1990) unit-root tests with an exogenous break to consider a number of events that took place in the U.S. economy over the period under study. 
Such events modify the productivity slowdown that began in 1974 and lasted through the firsthalf of the 1990s, the Tax Reform Act of 1986, and the 1980-82 and 1990-91 recessions, and finally the 1980-82 Volker era of monetary aggregates targeting regime. The results, also reported in Table 1, reject non-stationarity in the first differences of the variables under study.

\section{The Determinants of TFP}

We first derive the TFP measure from a production function specification based on the original approach suggested by Solow (1956). Following that method, TFP equals the component of output that does not reflect the accumulation of inputs. To keep the modeling simple, the analysis adopts, as a first approximation, the Cobb-Douglas production function. In that model and in an economy with two factors of production, the TFP variable comes out of a deterministic relation as follows:

$$
\ln T F P=\ln Y-\theta_{1} \ln K-\theta_{2} \ln L
$$

where $\mathrm{Y}$ equals output, $\mathrm{L}$ equals the labor employed, $\mathrm{K}$ equals the capital stock, $\theta_{l}$ equals the share of capital in GDP, while $\theta_{2}$ equals the share of labor in GDP. The figures from the two shares come from Garcia-Mila et al. (1996). Hsing (1996) and Fernald and Ramnath (2004) also reach similar results. Thus, the share of capital equals 0.30 and that of labor equals 0.70 , which produces our time series for TFP.

We next adopt a version of the model used by Coe and Helpman (1995), Braun and Evans (1998), and Haskel and Slaughter (2001) to examine the determinants of TFP. In particular, we assume that the determination of TFP is given as follows:

$$
T F P_{t}=\sum_{i=1}^{4} \delta_{i} Y_{i t}+\sum_{j=1}^{m} \mu_{i} D_{j t}+\varepsilon_{t}
$$

where $\left\{Y_{i t}\right\}$ equals a vector of underlying regressors, which drive TFP over time, and $\left\{D_{j t}\right\}$ 
equals a vector of dummy variables that correspond to the economic events mentioned in section B. For the purposes of our empirical analyses, we assume that the $\left\{Y_{i t}\right\}$ vector includes a monetary policy proxy, the state of technology (proxied by the number of patents), adjustment costs, and the capacity utilization ratio. Details on the estimation of adjustment costs appear in the Appendix. Therefore, we regress TFP onto a monetary policy variable-- the federal funds rate, non-borrowed reserves, or the ratio of non-borrowed reserves to total reserves, the state of technology, the adjustment cost, and the capacity utilization ratio. ${ }^{3}$ Both the adjustment cost variable and the utilization ratio play a potentially important role in understanding business cycle volatility, and especially substantial changes in productivity.

If we estimate equation (2) directly, then we assume that the right-hand-side variables in the regression are exogenous determinants. Rather than make this exogeneity assumption, we embed equation (2) into a vector error-correction (VEC) model, where the variables in the VEC are potentially endogenous. But to do so, we must first determine whether a Vector Autoregressive (VAR) or a VEC specification more properly fits the variables under study, we perform the Johansen and Juselius (1990) cointegration tests. The tests provide evidence in favor of cointegration between TFP, on one hand, and the number of patents, adjustment costs, the capacity utilization ratio, and each of the monetary policy proxies, on the other hand. Cointegration implies a long-run trend relationship between the variables included in the cointegration test. Then the VEC models the short-run dynamics around that long-run equilibrium relationship identified by the cointegration test.

\footnotetext{
3 Some authors employ human capital as a determinant of TFP. Results prove mixed. Islam (1995) reports insignificant effects for the role of human capital, while Benhabib and Spiegel (1994) find that human capital matters, but not for the level of TFP but rather for the growth rate (catch up effect) in TFP. By contrast, Mankiw et al. (1992) reach the opposite results. Miller and Upadhyay (2000) discover that human capital interacts with openness to affect TFP. We choose to omit human capital from our current analysis.
} 
Table 2 reports the cointegration results, making use of the three proxies for monetary policy. Both the eigenvalue test statistics and the trace test statistics indicate that a single longrun relationship between TFP and the variables under study exists. Given the support for a cointegrating relationship between TFP and the remaining variables, we specify an associated all-encompassing VEC system, which describes the short-run dynamics. Finally, the same conclusion holds for the annual measure of MFP and the federal funds rate.

\section{Variance Decompositions: Identifying the Sources of TFP Changes}

This section determines quantitatively the degree of importance of the factors that influence TFP beyond the sample period under study. Given cointegration among the variables under investigation, we construct VEC models for the different measures of monetary policy. The VEC models also include dummy variables associated with the events reported in the integration testing section. We decompose the total variance of TFP in each of the future periods and determine how much of this variance each factor explains. More explicitly, the variance decomposition informs about how much of the on-going variance of a particular variable's volatility, say TFP, gets explained by shocks to TFP and by shocks to the other variables in the VEC system. For example, if the movement in TFP proves largely exogenous and not responsive to movements in the other variables, then the movement in TFP largely reflects shocks to TFP and not shocks to the other variables.

Therefore, we calculate the response of TFP changes to a one standard deviation innovation in each factor for horizons up to 20 quarters. ${ }^{4}$ The VEC model equals the following

\footnotetext{
${ }^{4}$ To undertake the variance decomposition, we employ a Choleski ordering with the monetary policy variable first, followed by in order adjustment cost, the number of patents, the utilization rate, and, finally, TFP. The Choleski ordering implies that the current period the direct effect on the monetary policy variable comes from the monetary policy variable shock (innovation) and not from shocks to any of the other variables. The second variable in the Choleski ordering, the adjustment cost, gets directly affected in the current period by both the monetary policy variable and adjustment cost shocks, but not by any of the three remaining shocks. And so on. In all future periods
} 
specification:

$$
\Delta Y_{t}=\Gamma_{0}+\Gamma_{1} \Delta Y_{t-1}+\Gamma_{2} \Delta Y_{t-2}+\Gamma_{3} E C_{t-1}+\Gamma_{4} D U M_{t-1}^{\prime}+\varepsilon_{t} ; \varepsilon_{\mathrm{t}} \propto N(0, \Sigma)
$$

where $Y_{t}$ equals the 5 by 1 vector of TFP, the monetary policy proxy, patents, adjustment costs, and the capacity utilization ratio; $\Gamma_{1}$ and $\Gamma_{2}$ equal 5 by 5 matrices of parameters; $\Gamma_{3}$ equals a 5 by $\mathrm{r}$ matrix of parameters, where $\mathrm{r}$ equals the number of cointegrating vectors; $\Gamma_{4}$ equals a 5 by m matrix of parameters, where $\mathrm{m}$ equals the number of dummy variables, and, finally, $\Gamma_{0}$ and $\varepsilon_{t}$ equal 5 by 1 vectors of intercepts and the aforementioned variables' innovations.

Table 3 reports the variance of the forecast error of TFP changes and its decomposition into proportions attributable to random innovation shocks to each factor, including its own. Since TFP lies last in the Choleski ordering, it gets affected directly by shocks (innovations) to all variables in the VEC system, including its own shock. The results suggest that over the entire horizon shocks to the monetary policy variables account for the majority of the variation in TFP, followed by adjustment costs and the utilization ratios. For example, federal funds rate shocks explain 52.5 percent the forecast variance of TFP over one quarter and 35.3 percent over 20 quarters. The forecasting capacity of the proxy of monetary policy weakens over the long-run horizon, as both adjustment costs and utilization ratios strengthen their explanatory capacity. Table 3 also reports robustness tests by considering alternative proxies, non-borrowed reserves and non-borrowed reserves to total reserves. In both cases, the proxies for monetary policy play a significant role in explaining short- as well as long-run TFP behavior, 47.6 and 49.2 percent, respectively, in one quarter and 31.2 and 36.5 percent, respectively, over 20 quarters. Moreover, Table 3 reports variance decompositions of TFP, measured by the BLS as annual MFP, and the

each shock (innovation) can affect each variable's movement indirectly through the VEC system. For our current paper, we consider the long-run contributions to explaining the movement of TFP. 
federal funds rate to capture monetary policy. Once again, the empirical findings display that over the entire horizon ( 1 to 10 years) shocks to the federal funds rate account for the majority of the variation in TFP, following by adjustment costs and the utilization ratios. In particular, monetary policy shocks explain 44.7 percent of the forecast variance of TFP over one year and 32.6 percent over 10 years.

E. Conditional Volatility Estimates: Spillover Effects Between TFP Volatility and Money Volatility

Since the early 1970s, flexible exchange rates, OPEC price shocks, and other macroeconomic events have contributed to increased volatility in macroeconomies. Moreover, as mentioned earlier in this paper, the early 1980s witnessed a diminution of macroeconomic volatilities. Thus, for over 30 years, macroeconomists have examined not only the relationship between the changes in macroeconomic variables, but also the relationship between macroeconomic variables and their volatility. This section considers the potential relationship between monetary policy volatility and TFP volatility that employs a technique for modeling the time series movement in volatilities.

We develop a parsimonious augmented multivariate generalized autoregressive conditional heteroskedasticity (MVGARCH) model, which is a special case of an autoregressive moving- average (ARMA) process applied to the squared stochastic error term (see Engle and Kroner, 1995 and Lee, 1999). A Box-Jenkins selection procedure indicates that a MVGARCH $(1,1)$ model exhibits the best fit. We also experiment with higher lags in the MVGARCH specification, but they prove statistically insignificant. Thus, we estimate the following equations:

$$
\Delta Y_{t}=\Gamma_{0}+\Gamma_{1} \Delta Y_{t-1}+\Gamma_{2} \Delta Y_{t-2}+\Gamma_{3} E C_{t-1}+\Gamma_{4} D U M_{t-1}^{\prime}+\varepsilon_{t} ; \varepsilon_{\mathrm{t}} \propto N\left(0, H_{t}\right)
$$




$$
H_{t}=\mathrm{X}^{\prime} \mathrm{X}+A^{\prime} H_{t-1} A+B^{\prime} \varepsilon_{t-1} \varepsilon_{t-1}^{\prime} B, \text { where } \mathrm{t}=1, \ldots, \mathrm{T},
$$

where $H_{t}$ equals a $5 \times 5$ matrix of the conditional variances-covariances for TFP, the monetary policy proxy, patents, adjustment costs, and the capacity utilization ratio; $A$ and $B$ equal 5 by 5 matrices of parameters; and $X$ equals a 5 by 5 upper-triangular matrix of parameters. That is, the equations in system (4) constitute the VEC for the five variables considered in system (3). Now, the equations in system (5) introduce the relationships, if any, between the volatilities of the five variables. Concentrating only on the two variables of interest -- TFP and the monetary policy proxy, we illustrate the specification for these two variables within the entire augmented MVGARCH model, where we use the federal funds rate as our monetary policy proxy:

$$
\begin{aligned}
& \Delta T F P_{t}=\gamma_{0}^{T F P}+\gamma_{1}^{T F P, T F P} \Delta T F P_{t-1}+\gamma_{2}^{T F P, T F P} \Delta T F P_{t-2}+\ldots+\gamma_{1}^{T F P, U T I L} \Delta U T I L_{t-1} \\
&+\gamma_{2}^{T F P, U T I L} \Delta U T I L_{t-2}+\gamma_{3}^{T F P} E C_{t-1}+\gamma_{4}^{T F P} D_{t}+\varepsilon_{t}^{T F P} ; \\
& \Delta F F R_{t}=\gamma_{0}^{F F R}+\gamma_{1}^{F F R, T F P} \Delta T F P_{t-1}+\gamma_{2}^{F F R, T F P} \Delta T F P_{t-2}+\ldots+\gamma_{1}^{F F R, U T I L} \Delta U T I L_{t-1} \\
& \quad+\gamma_{2}^{F F R, U T I L} \Delta U T I L_{t-2}+\gamma_{3}^{F F R} E C_{t-1}+\gamma_{4}^{F F R} D_{t}+\varepsilon_{t}^{T F P} ; \\
& h_{t}^{T F P}= \\
& \chi_{T F P, T F P}^{2}+\chi_{T F P, F F R}^{2}+\ldots+\chi_{T F P, U T I L}^{2}+\beta_{T F P, T F P}^{2} \varepsilon_{T F P, t-1}^{2}+\beta_{T F P, F F R}^{2} \varepsilon_{F F R, t-1}^{2}+\ldots \\
&+\beta_{T F P, U T I L}^{2} \varepsilon_{U T I L, t-1}^{2}+2 \beta_{T F P, T F P} \beta_{T F P, F F R} \varepsilon_{T F P, t-1} \varepsilon_{F F R, t-1}+\ldots \\
&+2 \beta_{T F P, T F P} \beta_{T F P, U T L L} \varepsilon_{T F P, t-1} \varepsilon_{U T I L, t-1}+\ldots(\mathrm{cross}-\mathrm{terms})+\alpha_{T F P, T F P}^{2} h_{t-1}^{T F P} \\
&+\alpha_{T F P, F F R}^{2} h_{t-1}^{F F R}+\ldots+\alpha_{T F P, U T L L}^{2} h_{t-1}^{U T L}+2 \alpha_{T F P, T F P} \alpha_{T F P, F F R} h_{t-1}^{T F P, F F R}+\ldots \\
&+
\end{aligned}
$$

and

$$
\begin{aligned}
h_{t}^{F F R}= & \chi_{F F R, T F P}^{2}+\chi_{F F R, F F R}^{2}+\ldots+\chi_{F F R, U T I L}^{2}+\beta_{F F R, T F P}^{2} \varepsilon_{T F P, t-1}^{2}+\beta_{F F R, F F R}^{2} \varepsilon_{F F R, t-1}^{2}+\ldots \\
& +\beta_{F F R, U T I L}^{2} \varepsilon_{U T I L, t-1}^{2}+2 \beta_{F F R, T F P} \beta_{F F R, F F R} \varepsilon_{T F P, t-1} \varepsilon_{F F R, t-1}+\ldots \\
& +2 \beta_{F F R, T F P} \beta_{F F R, U T L L} \varepsilon_{T F P, t-1} \varepsilon_{U T I L, t-1}+\ldots(\mathrm{cross}-\mathrm{terms})+\alpha_{F F R, T F P}^{2} h_{t-1}^{T F P} \\
& +\alpha_{F F R, F F R}^{2} h_{t-1}^{F F R}+\ldots+\alpha_{F F R, U T I L}^{2} h_{t-1}^{U T I L}+2 \alpha_{F F R, T F P} \alpha_{F F R, F F R} h_{t-1}^{T F P, F F R}+\ldots \\
& +2 \alpha_{F F R, T F P} \alpha_{F F R, U T I L} h_{t-1}^{T F P, U T I L}+\ldots(\mathrm{cross}-\text { terms }),
\end{aligned}
$$

where $\varepsilon^{F F R}$ and $\varepsilon^{T F P}$ equal stochastic disturbance terms of the mean process for the funds rate and 
TFP, respectively, and $\mathrm{D}^{\prime}$ equals a vector of dummy variables (mentioned in the integration analysis section). Finally, $h^{T F P}, h^{F F R}, h^{P A T}, h^{J}$, and $h^{U T I L}$ equal the conditional variances of TFP, the funds rate, patents, adjustment costs, and capacity utilization ratio, respectively. Focusing on equations (8) and (9), the coefficient $\alpha_{T F P, F F R}$ captures spillover effects from the funds rate volatility onto TFP volatility. Similarly, the coefficient $\alpha_{F F R, T F P}$ captures spillover effects from TFP volatility onto the federal funds rate volatility. We employ maximum likelihood techniques proposed by Bollerslev and Wooldridge (1992) to estimate heteroskedasticity-consistent parameter estimates of the MVGARCH model. Assuming conditional normality, we jointly estimate the model by maximizing the following log-likelihood function:

$$
\log L(\Theta)=-\frac{1}{2} \sum_{t=1}^{T}\left[\ln \left|H_{t}(\Theta)\right|+\varepsilon_{t}^{\prime}(\Theta) H_{t}^{-1}(\Theta) \varepsilon_{t}(\Theta)\right]
$$

where $\Theta$ equals the parameter vector of the estimated model, $T$ equals the number of observations, $\varepsilon_{t}$ equals the 5 by 1 vector of residuals, and $H_{t}$ equals the 5 by 5 matrix of conditional variances and covariances defined above.

We concentrate only on the estimates of the two relevant equations -- the monetary policy proxy and TFP volatility equations. Table 4 reports the empirical results on conditional estimates for the two variables under consideration, where the federal funds rate measures monetary policy. ${ }^{5}$ The numbers in parentheses are robust t-statistics to allow for possible violations of normality for the conditional errors (Bollerslev and Wooldridge, 1992). Table 4 also illustrates the results of several diagnostic tests for the MVGARCH model specification. The statistics show the absence of serial correlation or ARCH effects in the residuals, while the Bollerslev's (1988) LM test rejects model misspecification. Overall, the diagnostic statistics strongly support

\footnotetext{
${ }^{5}$ The authors will provide the estimates of the remaining equations on request.
} 
the MVGARCH(1,1) model as a good description of the stochastic behavior of the conditional volatility of money supply and TFP. In addition, we report the constancy tests, proposed by Chu (1995), for the estimated equations. The statistics, in those tests, fall below the corresponding critical values (a non-zero p-value), implying acceptance of the null hypothesis of parameter constancy. Ljung-Box statistics of the standardized and the squared standardized residuals also prove insignificant, implying proper model specification with the absence of serial correlation and of $\mathrm{ARCH}$ effects, respectively. Finally, the $\mathrm{TR}^{2}$ statistic provides robustness support for the absence of time-varying variance.

Some parameters in matrix A depict the extent to which the current levels of conditional variances correlate with their own past levels. The results show that the coefficient estimates for the lagged variance terms of TFP and the federal funds rate in the TFP and federal funds rate conditional variance equations, respectively, prove positive and statistically significant in both equations at the 1-percent level (i.e., $\alpha_{T F P, T F P}$ and $\left.\alpha_{F F R, F F R}\right)$. Their relatively high values imply that a current shock will produce relatively long lasting effects on the future levels of the two conditional variances. In addition, other parameters in matrix A capture the extent to which the conditional variances of the TFP and the funds rate correlate with the lagged conditional variances of the funds rate and TFP, respectively (i.e., $\alpha_{T F P, F F R}$ and $\alpha_{F F R, T F P}$ ), the cross-equation effects. The estimates prove positive and statistically significant at the 1-percent level, identifying that monetary policy and TFP volatility reinforce each other. That is, higher (lower) federal funds rate volatility associates with higher (lower) TFP volatility, and vice versa.

Some parameters in matrix B reveal the extent to which the conditional variances of the TFP and the funds rate correlate with their own past squared innovations (i.e., the residuals from the level models), respectively (i.e., $\beta_{T F P, T F P}$ and $\beta_{F F R, F F R}$ ) as well as the past squared innovation 
of the funds rate and TFP, respectively (i.e., $\beta_{T F P, F F R}$ and $\beta_{F F R, T F P}$ ), the cross-equation effects. The estimates prove positive and statistically significant at the 1-percent level, lending support to the presence of a cross-effect from a monetary policy shock to TFP volatility. That is, higher (lower) federal funds rate shocks associate with higher (lower) TFP volatility, and vice versa.

The reported results in Table 4 also support the importance of monetary policy volatility in explaining TFP volatility. The positive coefficient on the federal funds rate volatility indicates that higher (lower) lagged federal funds rate conditional variance raises (reduces) TFP conditional variance. Moreover, higher (lower) lagged TFP conditional variance raises (reduces) the federal funds rate conditional variance. Thus, the conditional volatility of monetary policy significantly affects real variables, such as TFP volatility.

Tables 5, 6, and 7 repeat the tests reported in Table 4 under three robustness tests -- two use alternative monetary policy measures, that is, non-borrowed reserves and non-borrowed reserves to total reserves, respectively, while the third test uses the annual BLS measure of Multifactor Productivity (MFP) along with the federal funds rate for the monetary policy proxy. The reported results reinforce the findings reported in Table 4, indicating the significance of monetary policy volatility in explaining TFP volatility.

\section{Concluding Remarks and Policy Implications}

This paper empirically assesses whether monetary policy affects the supply side of the macroeconomy. More specifically, we consider how three measures of monetary policy - the federal funds rate, non-borrowed reserves, and non-borrowed reserves to total reserves - and their volatilities affect TFP and its volatility in the U.S. economy. The results show that monetary policy proxies and their volatility exert a positive and statistically significant effect on TFP and its volatility. 
We employ two different econometric methods to examine the issues. First, we estimate a vector error-correction (VEC) model for five variables - TFP, a monetary policy proxy, the number of patents, adjustment cost, and the capacity utilization rate. The variance decompositions consider how shocks to the five variables explain the movements in these five variables into the long run. We find that the monetary policy proxies all explain the largest fraction of TFP movement in both the short and long run. Second, we estimate a multivariate generalized autoregressive conditional heteroskedasticity (MVGARCH) specification of the error structure of the five-variable VEC system. We find that monetary policy volatility significantly and positively affects TFP volatility.

The positive effect of monetary policy and its volatility on TFP and its volatility holds direct practical implications for domestic economic policy. In particular, the implementation of a countercyclical monetary policy seems to be the most appropriate to smooth out business cycle fluctuations. Monetarists argue that active monetary policy seems to be the primary reason for amplified business cycles (destabilizing intervention, Karras and Song 1996). Such views focus on how monetary policy affects aggregate demand. Our focus considers how monetary policy affects aggregate supply through productivity shocks. That is, we explore a broadened real business cycle theory whereby monetary policy affects real-side, productivity shocks. As such, the central banks should seriously consider the target of output stability in developing optimal monetary policy.

Most recently, the literature on the Great Moderation (e.g., Chatterjee, 1999; Kim and Nelson, 1999; McConnell and Perez-Quiros, 2000; Stock and Watson, 2002) considers a couple of potential alternative explanations for the decreased volatility of real GDP - the monetary authorities learned how to control economic fluctuations or the economy experienced a run of 
good luck. In addition, rising productivity growth followed shortly on the heals of the Great Moderation. Our findings suggest that monetary policy played a role in the rising productivity as well as the decline in the volatility of macroeconomic variables.

A potential extension of the paper can examine the relationship between monetary policy volatility and TFP volatility in an open economy framework, where monetary policy can affect the real exchange rate, which, in turn, could amplify output volatility (Iscan and Osberg, 1998).

\section{Appendix}

Braun and Evans (1998) introduce an economy with a technology that produces goods $\left(Y_{t}\right)$, using capital $\left(K_{t}\right)$ and labor hours $\left(L_{t}\right)$ with the following production with random technology shock $\left(Z_{t}\right)$ and adjustment costs $\left(J_{t}\right)$ :

$$
\begin{aligned}
& Y_{t}=Z_{t} K_{t}^{\theta} L_{t}^{1-\theta} J_{t}, 0<\theta<1 ; \text { and } \\
& Z_{t}=Z_{t-1} \exp \left(\lambda+\varepsilon_{t}\right) .
\end{aligned}
$$

From (A1), production responds to technology shocks and adjustment costs on capital and labor. The state of technology in equation (A2) follows a random walk process with drift $(\lambda)$, while $\varepsilon_{\mathrm{t}}$ equals a serially uncorrelated random variable.

The adjustment costs relate to the cost of adjusting capital and labor hours in terms of lost output and get estimated through the following specification:

$$
J_{t}=\exp \left\{-\frac{\psi_{1}}{2}\left[\frac{\left(K_{t+1}-K_{t} \exp \left(\lambda+\varepsilon_{t}\right)\right.}{K_{t}}\right]^{2}-\frac{\psi_{2}}{2}\left[\frac{L_{t}-L_{t-1}}{L_{t-1}}\right]^{2}\right\},
$$

where $\psi_{1}$ and $\psi_{2}$ equal positive parameters and $\lambda$ equals the average growth rate of capital as well as the technology. The first term relates the adjustment cost to the increase of the capital stock at a rate other than the average growth rate, while the second term relates the adjustment cost to the increase in labor hours at a rate other than its unconditional growth rate, which equals 
zero. By making use of the estimated parameters given in Braun and Evans (1998), we determine from (A3) a value for $J_{t}$. The parameter $\lambda$ and the residual $\varepsilon_{t}$ in (A3) are estimated through (A2).

To this end, we employ the number of patents as a proxy for the state of technology (Englander et al., 1988).

\section{References}

Basu, S. (1996), "Procyclical productivity: Increasing returns or cyclical utilization?" Quarterly Journal of Economics, 61, 719-51.

Basu, S. (1995), "Intermediate goods and business cycles: Implications for productivity and welfare," American Economic Review, 85, 512-31.

Basu, S. and Kimball, M. S. (1994), "Cyclical productivity with unobserved input Variation," Hoover Institution manuscript.

Beladi, H. and Samanta, S. K. (1988), "Unanticipated monetary policy and real output: some evidence from the UK economy," Applied Economics, 20, 721-30.

Benhabib, J. and Spiegel, M. M. (1994), "The role of human capital in economic development: Evidence from aggregate cross-country data," Journal of Monetary Economics, 34, 14373.

Bernanke, B. and Gertler, M. (1989), "Agency costs, net worth, and business Fluctuations," American Economic Review, 79, 14-31.

Blanchard, O. and Simon, J. (2001), "The long and large decline in U.S. output volatility," Brookings Papers on Economic Activity, 1, 135-164.

Boivin, J. and Giannoni, M. (2003), "Has monetary policy become more effective?" National Bureau of Economic Research, Working Paper No. 9459.

Bollerslev, T. (1988), "On the correlation structure of the generalized autoregressive conditional heteroskedastic process," Journal of Time Series Analysis, 9, 121-31.

Bollerslev, T. (1986), "Generalized autoregressive conditional heteroskedasticity," Journal of Econometrics, 31, 307-27.

Bollerslev, T. and Wooldridge, J. M. (1992), "Quasi-maximum likelihood estimation and inference in dynamic models with time-varying covariances," Econometric Reviews, 11, 143-72. 
Braun, A. R. and Evans, C. L. (1998), "Seasonal Solow residuals and Christmas: A case for labor hoarding and increasing returns," Journal of Money, Credit, and Banking, 30, 306-30.

Bruno, M. and Easterly, W. (1998), "Inflation crises and long-run growth," Journal of Monetary Economics, 41, 3-26.

Burdekin, R. C. K., Denzau, A. T., Keil, M. F., Sitthiyot, T., Willett, T. D. (2004), "When does inflation hurt economic growth? Different nonlinearities for different economies," Journal of Macroeconomics, 26, 519-32.

Caballero, R. J. and Lyons, R. K. (1992), "External effects in U.S. procyclical Productivity," Journal of Monetary Economics, 29, 209-63.

Chatterjee, S. (1999), "Real business cycles: A legacy of countercyclical policies?" Federal Reserve Bank of Philadelphia, Business Review, 17-27.

Chatterjee, S. (1995), "Productivity growth and the American business cycle," Federal Reserve Bank of Philadelphia, Business Review, 13-23.

Chowdhury, A. R. and Liu, Y. (1995), "Is money more productive in a developing economy?" Applied Economics Letters, 2, 118-21.

Christiano, L. J., Eickenbaum, M., and Evans, C. L. (1999), "Monetary policy shocks: What we have learned and to what end?" in Handbook of Macroeconomics, ed. J. B. Taylor and M. Woodford, Amsterdam: Elsevier/North-Holland.

Chu, C. S. J. (1995), "Detecting parameter shift in GARCH models," Econometric Reviews, 14, 241-66.

Clarida, R., Gali, J., and Gertler, M. (2000), "Monetary policy rules and macroeconomic stability: Evidence and some theory," Quarterly Journal of Economics, 147-180.

Coe, D. and Helpman, E. (1995), "International R\&D spillovers," European Economic Review, 39, 859-87.

DeLorme, C. D., Thompson, H. G., and Warren, R. S. (1995), "Money and production: a stochastic frontier approach," Journal of Productivity Analysis, 6, 333-42.

Dickey, D. A. and Fuller, W. A. (1981), "Likelihood ratio statistics for autoregressive time series with a unit root," Econometrica, 49, 1057-72.

Englander, S. A., Evenson, R. E., and Hanazaki, M. J. (1988), "R\&D, patenting and total factor productivity," OECD Economic Studies, 7-42.

Engle, R. F. and Kroner, K. F. (1995), "Multivariate simultaneous generalized ARCH," Econometric Theory, 11, 122-50. 
Evans, C. L. (1992), "Productivity shocks and real business cycles," Journal of Monetary Economics, 29, 191-208.

Fernald, J. G. and Ramnath, S. (2004), "The acceleration in U.S. total factor productivity after 1995: The role of information technology," Federal Reserve Bank of Chicago Economic Perspectives, 52-67.

Fisher, S. (1993), "The role of macroeconomic factors in growth," Journal of Monetary Economics, 32, 485-512.

Floden, M. (2000), "Endogenous monetary policy and the business cycle," European Economic Review, 44, 1409-29.

Garcia-Mila, T., McGuire, T. J., and Porter, R. H. (1996), "The effect of public capital in statelevel production functions reconsidered," Review of Economics and Statistics, 78, 17781.

Hasan, M. A. and Mahmud, S.F. (1993), "Is money and omitted variable in the production function? Some further results," Empirical Economics, 18, 431-45.

Haskel, J. and Slaughter, M. J. (2001), “Trade, technology and U.K. wage Inequality," The Economic Journal, 111, 163-87.

Hsing, Y. (1996), "An empirical estimation of regional production functions for the U.S. manufacturing industry," The Annals of Regional Science, 30, 351-58.

Iscan, T. and Osberg, L. (1998), "The link between inflation and output variability in Canada," Journal of Money, Credit, and Banking, 30, 261-72.

Islam, N. (1995), "Growth empirics: A panel data approach," Quarterly Journal of Economics, $110,1127-70$.

Johansen, S. and Juselius, C. (1990), "Maximum likelihood estimation and inference on cointegration-with applications to the demand for money," Oxford Bulletin of Economics and Statistics, 52, 169-210.

Jun, S. (1998), "Procyclical multifactor productivity: Tests of the current theories," Journal of Money, Credit, and Banking, 30, 51-63.

Kahn, J. A., McConnell, M. M. and Perez-Quiros, G. (2002), "On the causes of the increased stability of the U.S. economy," Federal Reserve Bank of New York Economic Policy Review, 183-202.

Karras, G. and Song, F. (1996), "Sources of business-cycle variability: An explanatory study on a sample of OECD countries," Journal of Macroeconomics, 18, 621-37. 
Kim, C. J. and Nelson, C. (1999), "Has the US economy become more stable? A Bayesian approach based on a Markov switching model of the business cycle," Review of Economics and Statistics, 81, 608-616.

Kydland, F. E. and Prescott, E. C. (1991), "Hours and employment variation in business cycle theory," Economic Theory, 1, 63-81.

Kydland, F. E. and Prescott, E. C. (1982), "Time to build and aggregate fluctuations," Econometrica, 50, 1345-70.

Kwiatkowski, D., Phillips, P., Schmidt, P., and Shin, Y. (1992), "Testing the null hypothesis of stationary against the alternative of a unit root: How sure are we that economic time series have a unit root?" Journal of Econometrics, 54, 159-78.

Lee, J. (1999), "The inflation and output variability tradeoff: Evidence from a GARCH model," Economics Letters, 62, 63-7.

Lucas, R. E. Jr. (1994), “Review of Milton Friedman and Anna J. Schwartz's 'A Monetary History of the United States, 1876-1960', Journal of Monetary Economics, 34, 5-16.

Mankiw, G. N., Romer, D., and Weil, D. N. (1992), "A contribution to the empirics of economic growth," Quarterly Journal of Economics, 107, 407-37.

McConnell, M. M. and Perez-Quiros, G. (2000), "Output fluctuations in the United States: What has changed since the early 80's?” American Economic Review 90, 1464-1476.

Miller, S. M. and Upadhyay, M. (2000), "The effects of openness, trade orientation, and human capital on total factor productivity," Journal of Development Economics, 63, 399-423.

Nourzad, F. (2002), "Real money balances and production efficiency: a panel data stochastic production frontier study," Journal of Macroeconomics, 24, 125-34.

Perron, P. (1990), "Testing for a unit root in a time series with a changing mean," Journal of Business and Economic Statistics, 8, 153-62.

Primiceri, G. E. (2003), “Time varying structural vector autoregressions and monetary policy," Working Paper, Princeton University.

Shapiro, M. D. (2003), "Regime shifts in economic growth: Assessing the evidence and the response of monetary policy," Paper presented at the Reserve Bank of New Zealand Research Conference, March 2003.

Short, E. D. (1079), "A new look at real money balances as a variable in the production function," Journal of Money, Credit and Banking, 11, 326-39. 
Sinai, A. and Stokes, H. H. (1972), "Real money balances: An omitted variable from the production function?" Review of Economics and Statistics, 54, 290-96.

Sims, C. A. (1980), "Macroeconomics and reality,” Econometrica, 48, 1-48.

Solow, R. (1957), "Technological change and the aggregate production function," Review of Economics and Statistics, 39, 312-320.

Solow, R. (1956), "A contribution to the theory of economic growth," Quarterly Journal of Economics, 70, 65-94.

Stock, J. H. and Watson, M. W. (2002), "Has the business cycle changed and why?" National Bureau of Economic Research Macroeconomics Annual 2002.

Tobin, J. (1965), “Money and economic growth,” Econometrica, 33, 671-84.

Walsh, C, E. (2003), Monetary Theory and Policy, MIT Press: Cambridge, MA. 
Table 1: Unit-Root Tests

\begin{tabular}{lcccc}
\hline \multirow{2}{*}{ ADF Tests } & \multicolumn{3}{c}{ With Trend } \\
\cline { 2 - 5 } & \multicolumn{3}{c}{ Without Trend } & \multicolumn{2}{c}{ Wirst } & $\begin{array}{c}\text { First } \\
\text { Variable }\end{array}$ & Levels & Difference & Levels & Difference \\
\cline { 2 - 5 } Y & $-1.54(4)$ & $-4.29(3)^{*}$ & $-1.63(4)$ & $-4.81(2)^{*}$ \\
FFR & $-1.35(3)$ & $-4.22(2)^{*}$ & $-1.78(3)$ & $-4.47(2)^{*}$ \\
NBR & $-1.28(3)$ & $-4.71(2)^{*}$ & $-1.63(3)$ & $-5.12(2)^{*}$ \\
TR & $-1.64(3)$ & $-4.85(2)^{*}$ & $-1.92(3)$ & $-5.47(2)^{*}$ \\
L & $-1.12(4)$ & $-10.15(2)^{*}$ & $-1.87(4)$ & $-10.74(2)^{*}$ \\
K & $-0.21(3)$ & $-5.08(2)^{*}$ & $-2.42(4)$ & $-5.16(1)^{*}$ \\
TFP & $-2.09(3)$ & $-20.54(2)^{*}$ & $-2.24(3)$ & $-20.68(2)^{*}$ \\
MFP & $-1.53(4)$ & $-12.36(2)^{*}$ & $-1.96(3)$ & $-14.28(2)^{*}$ \\
J & $-0.94(5)$ & $-7.38(2)^{*}$ & $-1.87(4)$ & $-7.79(1)^{*}$ \\
PAT & $-1.52(3)$ & $-4.48(2)^{*}$ & $-2.42(2)$ & $-4.53(1)^{*}$ \\
UTIL & $-2.08(3)$ & $-4.34(2)^{*}$ & $-2.32(2)$ & $-7.06(1)^{*}$ \\
& & & & \\
\hline
\end{tabular}

\section{KPSS Tests}

\begin{tabular}{lcccccccc} 
& \multicolumn{4}{c}{ Levels with Trend } & \multicolumn{5}{c}{ First Differences without Trend } \\
\cline { 2 - 9 } & \multicolumn{3}{c}{ Number of Lags } & & \multicolumn{3}{c}{ Number of Lags } \\
\cline { 2 - 9 } Variables & $\mathbf{0}$ & $\mathbf{2}$ & $\mathbf{4}$ & $\mathbf{8}$ & $\mathbf{0}$ & $\mathbf{2}$ & $\mathbf{4}$ & $\mathbf{8}$ \\
\hline Y & 1.23 & 1.02 & 0.83 & 0.63 & $0.15 \#$ & $0.13 \#$ & $0.13 \#$ & $0.16 \#$ \\
FFR & 1.85 & 1.41 & 1.13 & 0.93 & $0.18 \#$ & $0.17 \#$ & $0.16 \#$ & $0.11 \#$ \\
NBR & 1.36 & 1.21 & 1.07 & 0.85 & $0.17 \#$ & $0.15 \#$ & $0.15 \#$ & $0.09 \#$ \\
TR & 1.58 & 1.29 & 1.16 & 0.93 & $0.16 \#$ & $0.13 \#$ & $0.14 \#$ & $0.07 \#$ \\
L & 2.07 & 1.64 & 0.94 & 0.71 & $0.18 \#$ & $0.17 \#$ & $0.10 \#$ & $0.12 \#$ \\
K & 1.8 & 1.25 & 0.87 & 0.66 & $0.21 \#$ & $0.12 \#$ & $0.09 \#$ & $0.10 \#$ \\
TFP & 1.45 & 1.09 & 0.79 & 0.52 & $0.18 \#$ & $0.13 \#$ & $0.14 \#$ & $0.08 \#$ \\
MFP & 1.72 & 1.44 & 1.21 & 0.97 & $0.19 \#$ & $0.12 \#$ & $0.10 \#$ & $0.06 \#$ \\
J & 1.37 & 1.11 & 0.86 & 0.59 & $0.15 \#$ & $0.07 \#$ & $0.05 \#$ & $0.09 \#$ \\
PAT & 1.24 & 1.06 & 1.08 & 0.76 & $0.12 \#$ & $0.11 \#$ & $0.09 \#$ & $0.10 \#$ \\
UTIL & 1.13 & 1.11 & 1.01 & 0.65 & $0.14 \#$ & $0.10 \#$ & $0.14 \#$ & $0.11 \#$
\end{tabular}


Table 1: $\quad$ Unit-Root Tests (continued)

Perron Tests with Exogenous Breaks

\begin{tabular}{|c|c|c|c|c|c|c|c|c|}
\hline & \multicolumn{2}{|c|}{ Productivity Slowdown } & \multicolumn{2}{|c|}{ Tax Reform Act } & \multicolumn{2}{|c|}{$\begin{array}{c}\text { 1980-82 Recession and } \\
\text { Volker Era } \\
\end{array}$} & \multicolumn{2}{|c|}{ 1990-91 Recession } \\
\hline & Levels & $\begin{array}{c}\text { First } \\
\text { Difference }\end{array}$ & Levels & $\begin{array}{c}\text { First } \\
\text { Difference } \\
\end{array}$ & Levels & $\begin{array}{c}\text { First } \\
\text { Difference } \\
\end{array}$ & Levels & $\begin{array}{c}\text { First } \\
\text { Difference } \\
\end{array}$ \\
\hline $\mathbf{Y}$ & $-1.37(4)$ & $-4.74(3)^{*}$ & $-1.68(4)$ & $-4.59(3)^{*}$ & $-1.79(3)$ & $-4.96(2)^{*}$ & $-1.48(3)$ & $-4.75(2)^{*}$ \\
\hline FFR & $-1.58(3)$ & $-5.11(1)^{*}$ & $-1.52(3)$ & $-4.80(2)^{*}$ & $-1.66(4)$ & $-4.53(2)^{*}$ & $-1.95(3)$ & $-4.61(1)^{*}$ \\
\hline NBR & $-1.61(3)$ & $-4.73(2)^{*}$ & $-1.83(4)$ & $-4.69(3)^{*}$ & $-1.93(3)$ & $-4.92(2)^{*}$ & $-2.01(3)$ & $-4.58(2)^{*}$ \\
\hline TR & $-1.72(3)$ & $-4.81(1)^{*}$ & $-1.65(3)$ & $-4.56(2)^{*}$ & $-1.72(3)$ & $-4.79(1)^{*}$ & $-1.89(3)$ & $-4.81(2)^{*}$ \\
\hline $\mathbf{L}$ & $-1.28(3)$ & $-6.75(2)^{*}$ & $-1.49(3)$ & $-5.79(2)^{*}$ & $-1.17(3)$ & $-6.41(2)^{*}$ & $-1.36(2)$ & $-5.79(1)^{*}$ \\
\hline $\mathbf{K}$ & $-0.73(2)$ & $-5.49(1)^{*}$ & $-1.07(2)$ & $-5.38(1)^{*}$ & $-1.10(2)$ & $-5.20(1)^{*}$ & $-1.24(3)$ & $-5.84(2)^{*}$ \\
\hline TFP & $-1.95(3)$ & $-6.91(2)^{*}$ & $-1.58(3)$ & $-7.16(2)^{*}$ & $-1.85(3)$ & $-6.18(2)^{*}$ & $-1.55(3)$ & $-6.58(2)^{*}$ \\
\hline MFP & $-1.84(3)$ & $-5.28(2)^{*}$ & $-1.77(3)$ & $-5.11(2)^{*}$ & $-1.83(3)$ & $-4.90(2)^{*}$ & $-1.66(3)$ & $-5.28(2)^{*}$ \\
\hline $\mathbf{J}$ & $-0.86(4)$ & $-5.50(2)^{*}$ & $-0.91(3)$ & $-5.17(2)^{*}$ & $-0.76(4)$ & $-4.95(2)^{*}$ & $-0.93(3)$ & $-4.22(2)^{*}$ \\
\hline PAT & $-1.41(3)$ & $-4.71(2)^{*}$ & $-1.37(3)$ & $-4.94(2)^{*}$ & $-1.83(3)$ & $-4.89(2)^{*}$ & $-1.60(4)$ & $-4.74(3)^{*}$ \\
\hline UTIL & $-1.74(2)$ & $-4.63(1)^{*}$ & $-1.52(3)$ & $-4.59(2)^{*}$ & $-1.44(2)$ & $-4.35(1)^{*}$ & $-1.68(3)$ & $-4.68(2)^{*}$ \\
\hline
\end{tabular}

Notes: The Perron unit root test with an exogenous break is based on the regression:

$\Delta \mathrm{x}_{\mathrm{t}}=\mathrm{a}_{0}+\mathrm{a}_{1}$ TIME $+\mathrm{a}_{2} \mathrm{TT}+\mathrm{a}_{3}$ TB $+\mathrm{a}_{4} \mathrm{x}_{\mathrm{t}-1}+\sum_{\mathrm{i}=1}^{1} \mathrm{~g}_{\mathrm{i}} \Delta \mathrm{x}_{\mathrm{t}-\mathrm{i}}+\eta_{\mathrm{t}}$

where TT equals a dummy variable defined as: 0 values up to 1990:7 or 0 values up to 1987:1 or 0 values up to 1983:1 or 0 values up to 1992:1 and 1 thereafter; TB equals a dummy variable defined as: 1 at 1990:7 or 1 at 1987:1 or 1 at 1983:1 or 1 at 1992:1 and 0 otherwise. The figures in parentheses denote the number of lags in the tests that ensure white noise residuals.

* $\quad$ significant at the 1-percent level.

\# accepts the null hypothesis of stationarity at the 1-percent level 
Table 2: $\quad$ Cointegration Tests

\begin{tabular}{|c|c|c|c|c|c|}
\hline$r$ & $n-r$ & m. $\lambda$. & $95 \%$ & $\mathrm{Tr}$ & $95 \%$ \\
\hline$r=0$ & $r=1$ & 47.6780 & 31.00 & 74.5593 & 58.93 \\
\hline$r<=1$ & $r=2$ & 18.6488 & 24.35 & 28.7836 & 39.33 \\
\hline$r<=2$ & $r=3$ & 10.3841 & 18.33 & 12.0953 & 23.83 \\
\hline$r<=3$ & $r=4$ & 0.8752 & 11.54 & 0.8752 & 11.54 \\
\hline
\end{tabular}

II. TFP and Non-Borrowed Reserves

\begin{tabular}{|c|c|c|c|c|c|}
\hline$r$ & $n-r$ & $m . \lambda$. & $95 \%$ & $\operatorname{Tr}$ & $95 \%$ \\
\hline$r=0$ & $r=1$ & 44.8831 & 31.00 & 62.0852 & 58.93 \\
\hline$r<=1$ & $r=2$ & 22.0977 & 24.35 & 25.9733 & 39.33 \\
\hline$r<=2$ & $r=3$ & 12.4901 & 18.33 & 14.7391 & 23.83 \\
\hline$r<=3$ & $r=4$ & 1.3369 & 11.54 & 1.3369 & 11.54 \\
\hline \multicolumn{6}{|c|}{ III. TFP and Total Reserves } \\
\hline$\underline{r}$ & $n-r$ & m. $\lambda$. & $95 \%$ & $\operatorname{Tr}$ & $95 \%$ \\
\hline$r=0$ & $r=1$ & 39.8455 & 31.00 & 59.0085 & 58.93 \\
\hline$r<=1$ & $r=2$ & 20.9042 & 24.35 & 23.5529 & 39.33 \\
\hline$r<=2$ & $r=3$ & 13.2295 & 18.33 & 13.4873 & 23.83 \\
\hline$r<=3$ & $r=4$ & 2.3871 & 11.54 & 2.3871 & 11.54 \\
\hline
\end{tabular}

\section{Multifactor Productivity and the Federal Funds Rate}

\begin{tabular}{|c|c|c|c|c|c|}
\hline r & $n-r$ & $m . \lambda$. & $95 \%$ & $\mathrm{Tr}$ & $95 \%$ \\
\hline$r=0$ & $r=1$ & 46.7822 & 31.00 & 63.7921 & 58.93 \\
\hline$r<=1$ & $r=2$ & 21.2596 & 24.35 & 26.7295 & 39.33 \\
\hline$r<=2$ & $r=3$ & 12.1907 & 18.33 & 16.5491 & 23.83 \\
\hline$r<=3$ & $r=4$ & 3.4482 & 11.54 & 3.4482 & 11.54 \\
\hline
\end{tabular}

Notes: $r$ equals the number of cointegrating vectors, $n-r$ equals number of common trends, $m . \lambda$ equals the maximum eigenvalue statistic, Tr equals the Trace statistic. We determine the number of lags through Likelihood Ratio tests, developed by Sims (1980). 
Table 3: $\quad$ Variance Decompositions of TFP Changes

\begin{tabular}{|c|c|c|c|c|c|}
\hline \multicolumn{3}{|c|}{ I. Federal Funds Rate } & \multirow[b]{2}{*}{ LPAT } & \multirow[b]{2}{*}{ UTIL } & \multirow[b]{2}{*}{ TFP } \\
\hline Quarters & FFR & J & & & \\
\hline 1 & $\begin{array}{l}52.5^{*} \\
(4.33)\end{array}$ & $\begin{array}{l}17.0^{*} \\
(4.94)\end{array}$ & $\begin{array}{l}10.3^{*} \\
(2.38)\end{array}$ & $\begin{array}{l}13.7^{*} \\
(4.62)\end{array}$ & $\begin{array}{c}6.5^{*} \\
(1.29)\end{array}$ \\
\hline 4 & $\begin{array}{l}47.6^{*} \\
(6.62)\end{array}$ & $\begin{array}{l}20.4^{*} \\
(3.75)\end{array}$ & $\begin{array}{l}11.8^{*} \\
(3.39)\end{array}$ & $\begin{array}{c}17.5^{*} \\
(5.28)\end{array}$ & $\begin{array}{c}2.7^{*} \\
(0.97)\end{array}$ \\
\hline 12 & $\begin{array}{l}40.8^{*} \\
(3.63)\end{array}$ & $\begin{array}{l}23.8^{*} \\
(4.19)\end{array}$ & $\begin{array}{l}11.4^{*} \\
(2.47)\end{array}$ & $\begin{array}{l}21.8^{*} \\
(5.05)\end{array}$ & $\begin{array}{l}2.2 * * \\
(1.09)\end{array}$ \\
\hline 20 & $\begin{array}{l}35.3^{*} \\
(3.41) \\
\end{array}$ & $\begin{array}{l}25.7^{*} \\
(3.84) \\
\end{array}$ & $\begin{array}{l}11.8^{*} \\
(2.77) \\
\end{array}$ & $\begin{array}{l}24.6^{*} \\
(4.26) \\
\end{array}$ & $\begin{array}{c}2.6^{*} \\
(0.87) \\
\end{array}$ \\
\hline \multicolumn{6}{|c|}{ II. Non-Borrowed Reserves } \\
\hline Quarters & NBR & J & LPAT & UTIL & TFP \\
\hline 1 & $\begin{array}{l}47.6^{*} \\
(5.14)\end{array}$ & $\begin{array}{l}18.3^{*} \\
(4.65)\end{array}$ & $\begin{array}{l}11.6^{*} \\
(3.03)\end{array}$ & $\begin{array}{l}14.3^{*} \\
(5.37)\end{array}$ & $\begin{array}{c}8.2^{*} \\
(2.44)\end{array}$ \\
\hline 4 & $\begin{array}{l}41.4^{*} \\
(4.86)\end{array}$ & $\begin{array}{l}22.5^{*} \\
(4.21)\end{array}$ & $\begin{array}{l}13.2^{*} \\
(2.87)\end{array}$ & $\begin{array}{l}18.9^{*} \\
(5.11)\end{array}$ & $\begin{array}{c}4.0 \\
(2.07)\end{array}$ \\
\hline 12 & $\begin{array}{l}34.2^{*} \\
(3.95)\end{array}$ & $\begin{array}{l}25.8^{*} \\
(3.79)\end{array}$ & $\begin{array}{l}13.8^{*} \\
(2.25)\end{array}$ & $\begin{array}{l}22.3^{*} \\
(4.30)\end{array}$ & $\begin{array}{c}3.9^{*} \\
(1.21)\end{array}$ \\
\hline 20 & $\begin{array}{l}31.2 * \\
(3.38)\end{array}$ & $\begin{array}{l}27.9^{*} \\
(3.26)\end{array}$ & $\begin{array}{l}12.9^{*} \\
(2.28)\end{array}$ & $\begin{array}{l}25.1^{*} \\
(4.19)\end{array}$ & $\begin{array}{c}2.9^{*} \\
(1.12)\end{array}$ \\
\hline
\end{tabular}

III. Non-Borrowed Reserves to Total Reserves

\begin{tabular}{|c|c|c|c|c|c|}
\hline Quarters & NBRTR & $\mathbf{J}$ & LPAT & UTIL & TFP \\
\hline \multirow[t]{2}{*}{1} & $49.2 *$ & $18.6^{*}$ & $12.5^{*}$ & $12.6^{*}$ & $7.1^{* *}$ \\
\hline & (6.45) & $(4.58)$ & (3.49) & $(4.27)$ & (2.78) \\
\hline \multirow[t]{2}{*}{4} & $40.8^{*}$ & $22.5^{*}$ & $13.2^{*}$ & $19.8^{*}$ & 3.7 \\
\hline & $(5.72)$ & $(4.17)$ & $(3.21)$ & $(4.07)$ & (2.11) \\
\hline \multirow[t]{2}{*}{12} & $37.6^{*}$ & $24.4^{*}$ & $14.8^{*}$ & $22.3 *$ & 0.9 \\
\hline & $(4.88)$ & $(3.47)$ & $(3.10)$ & (3.94) & (1.68) \\
\hline \multirow[t]{2}{*}{20} & $36.5^{*}$ & $25.2 *$ & $15.3^{*}$ & $22.8^{*}$ & $0.2 *$ \\
\hline & $(4.35)$ & $(3.29)$ & $(2.53)$ & $(3.37)$ & $(0.05)$ \\
\hline
\end{tabular}

IV. Multifactor Productivity and the Federal Funds Rate

\begin{tabular}{llllll}
\hline Quarters & FFR & J & LPAT & UTIL & MFP \\
\hline $\mathbf{1}$ & $44.7^{*}$ & $14.8^{* *}$ & $11.6^{*}$ & $14.0^{*}$ & $14.9^{*}$ \\
& $(6.52)$ & $(6.81)$ & $(3.44)$ & $(5.27)$ & $(3.11)$ \\
$\mathbf{3}$ & $40.5^{*}$ & $18.4^{*}$ & $14.2^{*}$ & $17.5^{*}$ & $9.4^{*}$ \\
& $(6.14)$ & $(4.58)$ & $(4.21)$ & $(4.92)$ & $(2.19)$ \\
$\mathbf{7}$ & $35.9^{*}$ & $22.5^{*}$ & $17.2^{*}$ & $20.2^{*}$ & $4.2^{*}$ \\
& $(5.48)$ & $(5.27)$ & $(4.71)$ & $(5.37)$ & $(1.41)$ \\
$\mathbf{1 0}$ & $32.6^{*}$ & $25.7^{*}$ & $18.8^{*}$ & $22.6^{*}$ & $0.3^{*}$ \\
& $(4.72)$ & $(4.51)$ & $(4.19)$ & $(4.75)$ & $(0.07)$ \\
\hline
\end{tabular}

Notes: Figures in parentheses denote standard errors estimated through Monte Carlo techniques and 1000 replications.

* $\quad$ significant at 1-percent level

** $\quad$ significant at 5-percent level 


$\begin{array}{ll}\text { Table 4: } & \text { Estimates from the } h^{\text {TFP }} \text { and } h^{\text {FFR }} \text { Equations, The } \\ \text { Federal Funds Rate }\end{array}$

\begin{tabular}{|c|c|c|c|c|}
\hline \multicolumn{2}{|l|}{ Matrix A } & \multicolumn{3}{|c|}{ Matrix B } \\
\hline$\alpha_{\text {TFP,TFP }}$ & $0.447(5.71)^{*}$ & & $\beta_{\text {TFP,TFP }}$ & $0.174(4.19)^{*}$ \\
\hline$\alpha_{T F P, F F R}$ & $0.054(5.42)^{*}$ & & $\beta_{T F P, F F R}$ & $0.237(4.11)^{*}$ \\
\hline$\alpha_{F F R, T F P}$ & $0.014(5.63)^{*}$ & & $\beta_{\text {FFR,TFP }}$ & $0.165(3.77)^{*}$ \\
\hline$\alpha_{F F R, F F R}$ & $0.264(5.49)^{*}$ & & $\beta_{F F R, F F R}$ & $0.218(4.62)^{*}$ \\
\hline \multicolumn{5}{|c|}{ Diagnostic Statistics } \\
\hline$L(\Theta)$ & 2673.48 & & & \\
\hline LM1 & $10.45[0.27]$ & & & \\
\hline$L M 2$ & $6.32[0.32]$ & & & \\
\hline \multirow[t]{2}{*}{$L M 3$} & $7.81[0.37]$ & & & \\
\hline & $\Delta$ FFR & $\Delta \mathrm{TFP}$ & & \\
\hline$Q(1)$ & $0.75[0.60]$ & $0.48[0.63]$ & & \\
\hline$Q(4)$ & $3.44[0.36]$ & $1.17[0.57]$ & & \\
\hline$Q^{2}(1)$ & $3.11[0.41]$ & $2.74[0.34]$ & & \\
\hline$Q^{2}(4)$ & $3.29[0.33]$ & $2.84[0.31]$ & & \\
\hline$T R^{2}$ & $6.48[0.16]$ & $5.48[0.21]$ & & \\
\hline \multicolumn{5}{|c|}{ Bollerslev's LM Test } \\
\hline & $0.29[0.33]$ & $0.14[0.61]$ & & \\
\hline
\end{tabular}

Notes: Numbers in parentheses denote absolute quasi-maximum likelihood t-statistics developed by Bollerslev and Wooldridge (1992), while those in brackets denote p-values. $\mathrm{L}(\Theta)$ equals the function value. LM1, LM2, and LM3 equal constancy tests for the GARCH models [Chu (1995)]. Q and $\mathrm{Q}^{2}$ denote the Ljung-Box test for residual serial correlation and $\mathrm{ARCH}$, while $\mathrm{TR}^{2}$ denotes the test statistic for ARCH.

* $\quad$ significant at 1-percent level 
Table 5: Estimates from the $h^{\text {TFP }}$ and $h^{\text {NBR }}$ Equations, NonBorrowed Reserves

\begin{tabular}{|c|c|c|c|c|}
\hline \multicolumn{2}{|c|}{ Matrix A } & \multicolumn{3}{|c|}{ Matrix B } \\
\hline$\alpha_{T F P, T F P}$ & $0.369(4.12)^{*}$ & & $\beta_{\text {TFP,TFP }}$ & $0.162(4.49)^{*}$ \\
\hline$\alpha_{T F P, N B R}$ & $0.075(4.29)^{*}$ & & $\beta_{T F P, N B R}$ & $0.152(4.08)^{*}$ \\
\hline$\alpha_{N B R, T F P}$ & $0.016(4.62)^{*}$ & & $\beta_{N B R, T F P}$ & $0.184(3.91)^{*}$ \\
\hline$\alpha_{N B R, N B R}$ & $0.233(4.42)^{*}$ & & $\beta_{N B R, N B R}$ & $0.256(3.77)^{*}$ \\
\hline \multicolumn{2}{|c|}{ Diagnostic Statistics } & & & \\
\hline$L(\Theta)$ & 2945.61 & & & \\
\hline LM1 & $12.38[0.13]$ & & & \\
\hline LM2 & $8.71[0.27]$ & & & \\
\hline \multirow[t]{2}{*}{ LM3 } & $8.48[0.20]$ & & & \\
\hline & $\Delta \mathrm{NBR}$ & $\Delta \mathrm{TFP}$ & & \\
\hline$Q(1)$ & $0.63[0.66]$ & $0.31[0.71]$ & & \\
\hline$Q(4)$ & $2.35[0.41]$ & $1.36[0.48]$ & & \\
\hline$Q^{2}(1)$ & $2.26[0.49]$ & $2.09[0.42]$ & & \\
\hline$Q^{2}(4)$ & $3.11[0.39]$ & $2.46[0.38]$ & & \\
\hline$T R^{2}$ & $4.73[0.21]$ & $3.77[0.34]$ & & \\
\hline \multicolumn{5}{|c|}{ Bollerslev's LM Test } \\
\hline & $0.23[0.37]$ & $0.19[0.53]$ & & \\
\hline
\end{tabular}

Notes: See Table 4

* $\quad$ significant at 1-percent level 
Table 6: $\quad$ Estimates from the $h^{\text {TFP }}$ and $h^{\text {NBRTR }}$ Equations, NonBorrowed Reserves to Total Reserves

\begin{tabular}{|c|c|c|c|c|}
\hline \multicolumn{3}{|l|}{ Matrix A } & \multicolumn{2}{|l|}{ Matrix B } \\
\hline$\alpha_{T F P, T F P}$ & $0.328(4.01)^{*}$ & & $\beta_{\text {TFP,TFP }}$ & $0.1954 .52)^{*}$ \\
\hline$\alpha_{T F P, N B R T R}$ & $0.058(3.85)^{*}$ & & $\beta_{T F P, N B R T R}$ & $0.190(4.33)^{*}$ \\
\hline$\alpha_{N B R T R, T F P}$ & $0.023(4.22)^{*}$ & & $\beta_{\text {NBRTR,TFP }}$ & $0.226(4.62)^{*}$ \\
\hline$\alpha_{\text {NBRTRNBR,TR }}$ & $0.253(3.74)^{*}$ & & $\beta_{\text {NBRTR,NBRTR }}$ & $0.217(4.11)^{*}$ \\
\hline \multicolumn{2}{|c|}{ Diagnostic Statistics } & & & \\
\hline$L(\Theta)$ & 2877.18 & & & \\
\hline LM1 & $10.91[0.17]$ & & & \\
\hline LM2 & $6.54[0.39]$ & & & \\
\hline \multirow[t]{2}{*}{ LM3 } & $7.12[0.24]$ & & & \\
\hline & $\Delta \mathrm{TR}$ & $\triangle \mathrm{TFP}$ & & \\
\hline$Q(1)$ & $0.54[0.69]$ & $0.48[0.60]$ & & \\
\hline$Q(4)$ & $2.17[0.46]$ & $1.21[0.53]$ & & \\
\hline$Q^{2}(1)$ & $1.93[0.58]$ & $1.84[0.48]$ & & \\
\hline$Q^{2}(4)$ & $2.67[0.45]$ & $2.15[0.47]$ & & \\
\hline$T R^{2}$ & $3.81[0.29]$ & $3.26[0.39]$ & & \\
\hline \multicolumn{5}{|c|}{ Bollerslev's LM Test } \\
\hline & $0.28[0.33]$ & $0.23[0.47]$ & & \\
\hline
\end{tabular}

Notes: See Table 4.

* $\quad$ significant at 1-percent level 
Table 7: Estimates from the $h^{\text {MFP }}$ and $h^{\text {FFR }}$ Equations, Multifactor Productivity and Federal Funds Rate

\begin{tabular}{|c|c|c|c|c|}
\hline \multicolumn{3}{|c|}{ Matrix A } & \multicolumn{2}{|l|}{ Matrix B } \\
\hline$\alpha_{\text {MFPMTFP }}$ & $0.174(4.19)^{*}$ & & $\beta_{M F P, M F P}$ & $0.584(4.39)^{*}$ \\
\hline$\alpha_{M F P, F F R}$ & $0.057(4.39)^{*}$ & & $\beta_{M F P, F F R}$ & $0.275(4.41)^{*}$ \\
\hline$\alpha_{\text {FFRMTFP }}$ & $0.016(4.38)^{*}$ & & $\beta_{F F R, M F P}$ & $0.349(3.98)^{*}$ \\
\hline$\alpha_{F F R, F F R}$ & $0.218(4.62)^{*}$ & & $\beta_{F F R, F F R}$ & $0.271(4.18)^{*}$ \\
\hline \multicolumn{2}{|c|}{ Diagnostic Statistics } & & & \\
\hline$L(\Theta)$ & 2778.08 & & & \\
\hline LM1 & $11.28[0.23]$ & & & \\
\hline LM2 & $5.69[0.37]$ & & & \\
\hline \multirow[t]{2}{*}{ LM3 } & $6.33[0.42]$ & & & \\
\hline & $\Delta$ FFR & $\triangle \mathrm{MFP}$ & & \\
\hline$Q(1)$ & $0.53[0.67]$ & $0.62[0.68]$ & & \\
\hline$Q(4)$ & $2.92[0.33]$ & $1.36[0.59]$ & & \\
\hline$Q^{2}(1)$ & $2.83[0.38]$ & $2.13[0.32]$ & & \\
\hline$Q^{2}(4)$ & $3.15[0.36]$ & $2.24[0.36]$ & & \\
\hline$T R^{2}$ & $7.71[0.22]$ & $6.05[0.24]$ & & \\
\hline \multicolumn{5}{|c|}{ Bollerslev's LM Test } \\
\hline & $0.34[0.39]$ & $0.19[0.55]$ & & \\
\hline
\end{tabular}

Notes: See Table 4

* $\quad$ significant at 1-percent level 